$1-1-2019$

\title{
Corporations and Sustainability
}

\author{
Beate Sjåfjell \\ University of Oslo \\ Christopher Bruner \\ University of Georgia School of Law, christopher.bruner@uga.edu
}

University of Georgia School of Law

Research Paper Series

Paper No. 2019-36

Dean Rusk International Law Center

Research Paper Series

Paper No. 2019-12

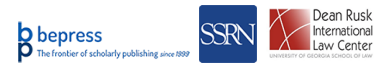

\section{Repository Citation}

Beate Sjåfjell and Christopher Bruner, Corporations and Sustainability The Cambridge Handbook Of Corporate Law, Corporate Governance and Sustainability (Christopher M. Bruner \& Beate Sjåfjell, eds. Cambridge University Press 2019) (with B. Sjåfjell). (2019),

Available at: https://digitalcommons.law.uga.edu/fac_artchop/1317

This Book Chapter is brought to you for free and open access by the Faculty Scholarship at Digital Commons @ University of Georgia School of Law. It has been accepted for inclusion in Scholarly Works by an authorized administrator of Digital Commons @ University of Georgia School of Law. Please share how you have benefited from this access For more information, please contact tstriepe@uga.edu. 
This is a preprint version of Chapter1 of B. Sjåfjell and C.M. Bruner (eds), Cambridge Handbook of Corporate Law, Corporate Governance and Sustainability (Cambridge University Press, 2019)

\section{Corporations and sustainability}

\section{Beate Sjåfjell and Christopher M. Bruner ${ }^{*}$}

\section{Establishing the field of corporate law, corporate governance and sustainability}

The ambition of this Handbook is to firmly establish sustainability-related study of corporate law and corporate governance as a field. This field of corporate law, corporate governance and sustainability is one of the most dynamic and significant areas of law and policy in light of the convergence of crises that we as a global society face. These include the environmental emergencies ultimately threatening humanity's existence, notably climate change and catastrophic biodiversity loss; ${ }^{1}$ the undermining of the economic bases for functioning societies, combined with rising inequality, leading to populism and unrest; ${ }^{2}$ and the lack of resilience and resulting instability of our financial systems, making new financial collapses more likely. ${ }^{3}$ As this Handbook explores in considerable depth, corporate law and corporate governance figure centrally in each of these forms of crisis, and accordingly must figure centrally in their resolution. Understanding the impact of the corporation on society and realizing its potential for contributing to sustainability is vital for the future of humanity.

The Handbook transcends the fragmented literature that reflects a traditional dichotomy between corporate law and corporate governance, on the one hand, and corporate social responsibility and socially responsible investment, on the other. It moves beyond discussions concentrating on soft-law guidelines, such as the UN Guiding Principles on Business and Human Rights and the OECD Guidelines for Multinational Enterprises, integrating these into a systemic and comprehensive analysis of

\footnotetext{
* This chapter draws on research in the project Sustainable Market Actors for Responsible Trade (SMART). SMART (2016-2020) has received funding from the European Union's Horizon 2020 research and innovation programme under Grant Agreement No 693642, and this support is gratefully acknowledged.

${ }^{1}$ V. Masson-Delmotte, P. Zhai, H.-O. Pörtner, D. Roberts, J. Skea, P.R. Shukla, A. Pirani, W. Moufouma-Okia, C. Péan, R. Pidcock, S. Connors, J.B.R. Matthews, Y. Chen, X. Zhou, M.I. Gomis, E. Lonnoy, Maycock, M. Tignor and T. Waterfield (eds.), Global Warming of $1.5^{\circ} \mathrm{C}$. An IPCC Special Report on the impacts of global warming of $1.5^{\circ} \mathrm{C}$ above pre-industrial levels and related global greenhouse gas emission pathways, in the context of strengthening the global response to the threat of climate change, sustainable development, and efforts to eradicate poverty (Geneva: World Meteorological Organization, 2018); J. Bélanger and D. Pilling (eds.), The State of the World's Biodiversity for Food and Agriculture (Rome: FAO Commission on Genetic Resources for Food and Agriculture Assessments, 2019); M. Grooten and R.E.A. Almond (eds.), Living Planet Report - 2018: Aiming Higher (Gland, Switzerland: WWF, 2018); J. Watts, 'Stop biodiversity loss or we could face our own extinction, warns UN', Guardian, 6 Nov. 2018, www.theguardian.com/environment/2018/nov/03/stopbiodiversity-loss-or-we-could-face-our-own-extinction-warns-un.

2 See e.g. J. Kelly, 'Europe's \$1 trillion tax gap', Financial Times, 21 Feb. 2019, https://ftalphaville.ft.com/2019/02/21/1550732404000/Europe-s--1-trillion-tax-gap/; F. Alvaredo, L. Chancel, T. Piketty, E. Saez and G. Zucman, World Inequality Report 2018, https://wir2018.wid.world/; and M. Cox, 'Understanding the Global Rise of Populism', Medium, 12 Feb. 2018, https://medium.com/@lseideas/understanding-the-global-rise-of-populism-27305a1c5355.

${ }^{3}$ C. Bruner, 'Corporate Governance Reform in Post-Crisis Financial Firms: Two Fundamental Tensions' (2018) 60 Arizona Law Review 959-86; International Monetary Fund, A Decade after the Global Financial Crisis: Are We Safer?, Global Financial Stability Report (Washington D.C.: International Monetary Fund, 2018), www.imf.org/en/Publications/GFSR/Issues/2018/09/25/Global-Financial-Stability-Report-October-2018; M. Wolf, 'Why so little has changed since the financial crash', Financial Times, 3 Sep. 2018, www.ft.com/content/c85b9792-aad1-11e8-94bd-cba20d67390c.
} 
This is a preprint version of Chapter1 of B. Sjåfjell and C.M. Bruner (eds), Cambridge Handbook of Corporate Law, Corporate Governance and Sustainability (Cambridge University Press, 2019)

corporate law and corporate governance within the framework of the overarching societal goal of sustainability.

In the corporate law and corporate governance literature, where environmental, social and economic sustainability issues have only begun to make inroads, the approach has tended be at most one of discussing the 'business case' for sustainability - that is, for internalising environmental and social impacts in corporate decision-making, but only to the degree that this has a positive effect on longterm financial performance. This resonates with the mainstream approach in economics, which implicitly assumes that financial value can be maximised using natural resources without the setting of any ecological limits. Such an approach effectively represents one of 'weak sustainability', which is also what we see in the most influential management literature, where discussions of business' contribution to sustainability have a longer history. ${ }^{4}$

The approach of our Handbook may, by contrast, be denoted a 'strong' sustainability approach. However, we emphasise that the concept of 'strong' sustainability simply means actual sustainability. Accordingly, real corporate sustainability must ultimately involve corporate legal and governance structures promoting practices that contribute to and, at a minimum, do not undermine society's potential for achieving the overarching goal of sustainability.

We understand sustainability as a state where the needs of the present generation are met 'while safeguarding Earth's life-support system, on which the welfare of current and future generations depends'. ${ }^{5}$ Accordingly, we take as our starting point the natural sciences concept of 'planetary boundaries' within which all human activity must be positioned to ensure a safe operating space for humanity. ${ }^{6}$ Planetary boundaries are not static, hard limits; rather they are continuous work-inprogress precautionary boundaries for which there is a strong consensus among the scientific community. ${ }^{7}$ Further, our understanding of sustainability is informed by recognition of the importance of protecting human rights and securing the fulfilment of fundamental social needs, acknowledging the economic and societal risks that pervasive inequality, globally and within countries, poses. In light of the foregoing, the grand challenge of sustainability is how to secure the social foundation for humanity everywhere, now and in the future, while remaining within planetary

\footnotetext{
${ }^{4}$ S.S. Vildåsen, M. Keitsch and A.M. Fet, 'Clarifying the Epistemology of Corporate Sustainability' (2017) 138 Ecological Economics 40-46.

${ }^{5}$ D. Griggs, M. Stafford-Smith, O. Gaffney, J. Rockström, M. C. Öhman, P. Shyamsundar, W. Steffen, G. Glaser, N. Kanie and I. Noble, 'Policy: Sustainable development goals for people and planet' (2013) 495 Nature 305-7. ${ }^{6}$ J. Rockström, W. Steffen, K. Noone, Å. Persson, F. S. I. Chapin, E. Lambin, T. Lenton, M. Scheffer, C. Folke, H. J. Schellnhuber, B. Nykvist, C. de Wit, T. Hughes, S. van der Leeuw, H. Rodhe, S. Sörlin, P. Snyder, R. Costanza, U. Svedin, M. Falkenmark, L. Karlberg, R. Corell, V. Fabry, J. Hansen, B. Walker, D. Liverman, K. Richardson, P. Crutzen and J. Foley, 'Planetary Boundaries: Exploring the Safe Operating Space for Humanity' (2009) 14 Ecology and Society; W. Steffen, K. Richardson, J. Rockström, S. E. Cornell, I. Fetzer, E. M. Bennett, R. Biggs, S. R. Carpenter, W. de Vries, C. A. de Wit, C. Folke, D. Gerten, J. Heinke, G. M. Mace, L. M. Persson, V. Ramanathan, B. Reyers and S. Sörlin, 'Planetary boundaries: Guiding human development on a changing planet' (2015) 347 Science 1259855.

${ }^{7}$ Steffen et al., 'Planetary boundaries: Guiding Human Development'; T. Sterner, 'Behind the paper: Policy design for the Anthropocene', Nature Sustainability, 10 Jan. 2019,

https://sustainabilitycommunity.nature.com/users/202079-thomas-sterner/posts/42831-policy-design-for-theanthropocene.
} 
This is a preprint version of Chapter1 of B. Sjåfjell and C.M. Bruner (eds), Cambridge Handbook of Corporate Law, Corporate Governance and Sustainability (Cambridge University Press, 2019)

boundaries. ${ }^{8}$ Drawing on state-of-the-art research in multiple fields, the core concepts of 'planetary boundaries' and the 'social foundation' constitute a communicative tool and an analytical framework within which to analyse and discuss corporate law and corporate governance, with the aim of achieving sustainability. ${ }^{9}$

The issues faced in the field of corporate law, corporate governance and sustainability are global by nature, and the Handbook accordingly presents significant developments in this dynamic area around the world to capture different perspectives and innovations. This includes innovations that occur outside of the mainstream and commercially predominant jurisdictions, which themselves have often reinforced pathologies that compromise sustainability. The Handbook provides a global review of sustainability-oriented initiatives pursued through corporate law and corporate governance that is, we believe, more comprehensive in its coverage and rigorous in its analytical framework than prior efforts in this field. Notably, it includes scores of contributors, jurisdictions, and subjects from every inhabited continent, addressing myriad issues and regulatory responses in a wide range of environmental, social, and economic settings.

The focus on the corporation is explained in Section 2 below, where we also preliminarily identify problems with the current approach to, and status of, corporate law and corporate governance. Thereafter we outline the concept of sustainability as the conceptual framework for this volume (Section 3), as well as the research questions that we address and the Handbook's structure (Section 4).

\section{The corporation and the unsustainability of current corporate law and corporate governance}

The legal form of the corporation ${ }^{10}$ remains the principal mode of organization for large, capitalintensive businesses, ${ }^{11}$ and their regulation is often the default point of reference in the law and policy of other business forms. ${ }^{12}$ Accordingly, while we acknowledge that other forms may offer intriguing possibilities (explored in various chapters of this Handbook), we see it as crucial to hone in on the regulation of this mainstream choice of legal form for large, capital-intensive business and to

\footnotetext{
${ }^{8}$ M. Leach, K. Raworth, and J. Rockström, 'Between social and planetary boundaries: Navigating pathways in the safe and just space for humanity', in World Social Science Report 2013: Changing Global Environments (Paris: OECD Publishing, 2013), pp. 84-90.

${ }^{9}$ We elaborate on this in Section 3 below.

${ }^{10}$ We use the terms 'corporation' and 'company' interchangeably throughout this Handbook to refer to the legal form that has the common characteristics across jurisdictions that it is a separate legal entity from its shareholders and has centralised decision-making under the auspices of its board, which exists in variations encompassing the two-tier system, seen notably in some Continental-European countries, and the single-tier system typical of common-law jurisdictions.

${ }^{11}$ This is not to say that the corporate form is used only for large, capital-intensive businesses. It is a dominant form for organising businesses ranging from small entrepreneurial activities where one person is the sole shareholder, the board and the only employee, to large, multinational entities.

${ }^{12}$ Likewise, the need for alternative forms is often justified by reference to the perceived constraints of the corporate form. V. Schnure Baumfield, 'How Change Happens: The Benefit Corporation in the United States and Considerations for Australia', in B. Sjåfjell and I. Lynch Fannon (eds.), Creating Corporate Sustainability. Gender as an Agent for Change (Cambridge: Cambridge University Press, 2018), pp. 188-212.
} 
This is a preprint version of Chapter1 of B. Sjåfjell and C.M. Bruner (eds), Cambridge Handbook of Corporate Law, Corporate Governance and Sustainability (Cambridge University Press, 2019)

investigate its weaknesses and strengths, its current state and emerging developments in the context of the goal of sustainability.

The corporation has been cited as one of the most ingenious legal inventions of modern history, ${ }^{13}$ making it possible for capital from many different investors to be channelled to risky business ventures that otherwise might not receive financing. Undertaking such business ventures through a separate legal entity, the corporation, makes it possible for investors to limit their liability to the creditors of the business while having a legitimate expectation of returns, typically through dividends or sale of the shares to other investors. The raising of capital and selling of shares is efficiently coordinated, both domestically and across borders, through modern stock exchanges. While the corporation is not inherently geared towards unsustainability, the uses toward which it has been put and the dominant legal-economic theories that have informed much of the mainstream corporate governance discourse certainly has resulted in unsustainable business practices. No jurisdiction's corporate law mandates the maximization of returns for shareholders to the detriment of other economic, social and environmental interests. Yet, an embedded challenge results from the fact that many people believe that it does, and act as if that were the case. ${ }^{14}$

By focusing on the corporation, we do not mean to suggest that business is contained within the boundaries of that single legal entity, which, as a 'creature of national law', ${ }^{15}$ lends itself to relatively uncomplicated domestic regulation. Quite the opposite; we recognize the fragmentation of responsibility and accountability through the organisation of business in corporate groups and through global value chains, obscuring control relationships and modes of production while defying territorially limited national regulation. ${ }^{16}$ This is combined with the opacity and complexity created, inter alia, through financial engineering and the proliferation of financial intermediaries, which mask the destination of beneficial investors' funds while narrowing evaluation of portfolio company performance through application of fiduciary or similar duties that emphasize maximizing investment returns to varying degrees. ${ }^{17}$ These prevailing dynamics reflect growing complexities that render more difficult both formal regulation and informal constraint through investment and consumer

\footnotetext{
${ }^{13}$ Whereas the enforceable contract may be the most innovative contribution of Roman law, see A. Watson, 'The evolution of law: the Roman system of contracts' (1984) 2 no. 1 Law and History Review 1 -20, company law may be said to have made a similar contribution to the contemporary economy, see R.G. Rajan and L. Zingales, Saving Capitalism from the Capitalists. Unleashing the Power of Financial Markets to Create Wealth and Spread Opportunity (New York: Crown Business, 2003).

${ }^{14}$ B. Sjåfjell, A. Johnston, L. Anker-Sørensen and D. Millon, 'Shareholder Primacy: The Main Barrier to Sustainable Companies', in B. Sjåfjell and B. J. Richardson (eds.), Company Law and Sustainability: Legal Barriers and Opportunities (Cambridge: Cambridge University Press, 2015), pp. 79-147; C.M. Bruner, Corporate Governance in the Common-Law World: The Political Foundations of Shareholder Power (Cambridge: Cambridge University Press, 2013).

15 This has been repeatedly emphasised by the Court of Justice of the European Union. See Daily Mail, Case 81/87 [1988] ECR 5483, 5511 [19]: 'companies are creatures of the law' and 'exist only by virtue of [...] national legislation which determines their incorporation and functioning'; repeated inter alia in Überseering, Case C208/00 [2002] ECR I-9943, I-9971 [81].

${ }^{16}$ E.g. J. Dine, The governance of corporate groups (Cambridge: Cambridge University Press, 2006); J. Bair, 'The Corporation and the Global Value Chain', in G. Baars and A. Spicer (eds.), The corporation. A critical, multidisciplinary handbook (Cambridge: Cambridge University Press, 2017), pp. 326-335.

${ }^{17}$ E.g. H.T.C. Hu and B. Black, 'Hedge funds, insiders, and the decoupling of economic and voting ownership: Empty voting and hidden (morphable) ownership' (2007) 13 Journal of Corporate Finance 343-67; L. AnkerSørensen, 'Financial Engineering as an Alternative Veil for the Corporate Group' (2016) 13 European Company Law, 158-66.
} 
This is a preprint version of Chapter1 of B. Sjåfjell and C.M. Bruner (eds), Cambridge Handbook of Corporate Law, Corporate Governance and Sustainability (Cambridge University Press, 2019)

markets, exacerbating the pathologies that arise from the narrow, yet pervasive, focus on generating returns for investors.

Corporate law and corporate governance concern the regulation of the most impactful units in our economies, and grappling with the challenges they present is therefore necessary to achieving sustainability. The idea that law and policy can be compartmentalized, with environmental issues left to environmental law, labour issues left to labour law, and so on, while imagining that the result will somehow become a consistent whole, is outdated and has proven unworkable in practice. In addition to the rampant problem with lack of legal compliance within national borders, the international and fragmented nature of business further challenges this assumption. The size, complexity and power of modern corporations highlight the fallacy of the silo approach to law and policy. Simply put, corporations can easily structure their businesses to evade a given jurisdiction's regulatory power.

\section{Sustainability: securing the social foundation within planetary boundaries}

Drawing on state-of-the-art research in natural sciences and other relevant fields, we set out here the understanding of sustainability that forms the backdrop for the other contributions to the Handbook. While the adoption of the United Nations Sustainable Development Goals (SDGs) ${ }^{18}$ has given new impetus to the debate on how to achieve sustainability, including in business and finance, we are still very much on unsustainable, path-dependent trajectories. To understand why and to find out how we can shift onto more sustainable paths, a research-based analytical framework for understanding the goal of sustainability, and the unsustainability of business as usual, is required.

Historically, sustainable development - or sustainability - has tended to be divided up into three pillars, with the equivalent 'triple-bottom line', or 'people, planet, profit', shaping the corporate social responsibility (CSR) movement. ${ }^{19}$ This informs so-called 'weak' sustainability with a trade-off mentality. Similarly, stakeholder theory, while recognizing a broader group of interests than shareholders alone ${ }^{20}$ typically does not recognize or engage with the existence of planetary boundaries, or necessarily encompass all groups affected by corporate decisions, such as people in affected communities across global value chains. ${ }^{21}$

\footnotetext{
${ }_{18}$ United Nations General Assembly resolution 70/1, Transforming Our World: The 2030 Agenda for Sustainable Development, A/RES/70/1 (25 September 2015), available at: www.undocs.org/A/RES/70/1. For additional background, see http://www.un.org/sustainabledevelopment/sustainable-development-goals/.

19 J. Elkington, 'Accounting for the triple bottom line' (1998) 2 Measuring Business Excellence 18-22. The inadequacy of the use of the triple bottom line is recognized also by Elkington himself, J. Elkington, ' 25 Years Ago I Coined the Phrase "Triple Bottom Line." Here's Why It's Time to Rethink It', Harvard Business Review, 25 June 2018, https://hbr.org/2018/06/25-years-ago-i-coined-the-phrase-triple-bottom-line-heres-why-im-givingup-on-it.

${ }^{20}$ Defined a starting point as 'any group or individual who can affect or is affected by the achievement of the firm's objectives', in the seminal publication R.E. Freeman, Strategic Management: A Stakeholder Approach (Boston: Pitman, 1984), at 46.

${ }^{21}$ See e.g. R.E. Freeman and S. Dmytriyev, 'Corporate Social Responsibility and Stakeholder Theory: Learning From Each Other' (2017) 1 Symphonya. Emerging Issues in Management.
} 
This is a preprint version of Chapter1 of B. Sjåfjell and C.M. Bruner (eds), Cambridge Handbook of Corporate Law, Corporate Governance and Sustainability (Cambridge University Press, 2019)

Our approach to sustainability is an integrated one, with the ecological limits of our planet, a prerequisite for achieving sustainability, forming the outer framework. 'Planetary boundaries', as a term used for the limits of our planet, is the result of the work of an international multidisciplinary group of environmental scientists, who in 2009 pooled their knowledge of different Earth system processes to inform the world about the space for sustainable action. ${ }^{22}$ Their work reflects the growing scientific understanding that life and its physical environment co-evolve. This pioneering effort brought together evidence of rising and interconnected global risks in several different contexts where environmental processes are being altered by human activities.

The planetary boundaries framework flags a set of sustainability-critical factors. It gives a dashboard of issues where our collective humanity is changing the fundamental dynamics of the Earth system most profoundly. ${ }^{23}$ Based on this work, it is estimated that humanity has already transgressed, or is at risk of transgressing, at least four of the currently identified nine planetary boundaries, including climate change, biosphere integrity, biogeochemical flows and land-system integrity. ${ }^{24}$ The planetary boundaries work is a continuous natural-science work-in-progress, as scientists gradually understand more of the complex interactions and feedback mechanisms in the global ecological systems. ${ }^{25}$ The concept of planetary boundaries forms the rationale by which new boundaries may be identified and better quantifications or metrics adopted. In line with this, the conceptual framework for planetary boundaries itself proposes a strongly precautionary approach, by 'setting the discrete boundary value at the lower and more conservative bound of the uncertainty range'. ${ }^{26}$ Bringing 'planetary boundaries' to bear upon corporate law and corporate governance accordingly connects with and better operationalises the environmental precautionary principle and the polluter pays principle. ${ }^{27}$

Introducing 'planetary boundaries' into corporate law and corporate governance is further significant on three levels. First and most importantly, it brings to the forefront that there are literal ecological limits and, conversely, that being perceived as 'environmentally friendly' is inadequate. Second, it highlights the complex interaction between planet-level environmental processes, and that climate change, however topical (and difficult to mitigate), is only one aspect of the convergence of crises we are facing. Third, it reminds us that state-of-the-art natural science must continue to inform our decisions on a work-in-progress-basis, emphasising the unacceptability of ignorance in the face of these severe environmental risks and the necessity of a knowledge-based precautionary approach.

The concept of a 'social foundation', which needs be secured within planetary boundaries, is a shortform for a range of interconnected issues. The social issues in the doughnut-shaped figure of the

\footnotetext{
${ }^{22}$ Rockström et al., 'Planetary boundaries: Exploring the safe operating space'; Steffen et al., 'Planetary boundaries: Guiding human development'. For additional background, see S. Cornell, 'Planetary Boundaries and Business: putting the operating into the Safe Operating Space for Humanity' (draft paper on file with current authors).

${ }^{23}$ Cornell, 'Planetary Boundaries and Business'.

${ }^{24}$ The other five are global freshwater use, ocean acidification, atmospheric aerosol loading, stratospheric ozone depletion, and novel entities. Steffen et al., 'Planetary boundaries: Guiding human development'.

${ }^{25}$ See T. Häyhäa, P.L. Lucas, D.P. van Vuuren, S.E. Cornell and H. Hoff, 'From Planetary Boundaries to national fair shares of the global safe operating space - How can the scales be bridged?' (2016) 40 Global Environmental Change 60.

${ }^{26}$ Rockström et al., 'Planetary boundaries: Exploring the safe operating space'.

${ }^{27}$ On precaution as an intrinsic element of the planetary boundaries approach, see Rockström et al., 'Planetary boundaries: Exploring the safe operating space'.
} 
This is a preprint version of Chapter1 of B. Sjåfjell and C.M. Bruner (eds), Cambridge Handbook of Corporate Law, Corporate Governance and Sustainability (Cambridge University Press, 2019)

'safe and just space for humanity' are illustrative, based originally on social issues on which there was some degree of consensus amongst governments for Rio $+20,{ }^{28}$ and later updated to include the social goals of the adopted SDGs. ${ }^{29}$ Yet, it is crucial to recognise that the minimum requirement intrinsic in securing the social foundation of humanity now and in the future is that of ensuring the realization of basic human rights, ${ }^{30}$ including the right to life (and thereby to sufficient water, food and medicine); the right to not be held in slavery or servitude; the right to equality and not to be discriminated against; and the right to work and to 'just and favourable conditions' of work, including remuneration ensuring for workers and their families 'an existence worthy of human dignity'. ${ }^{31}$

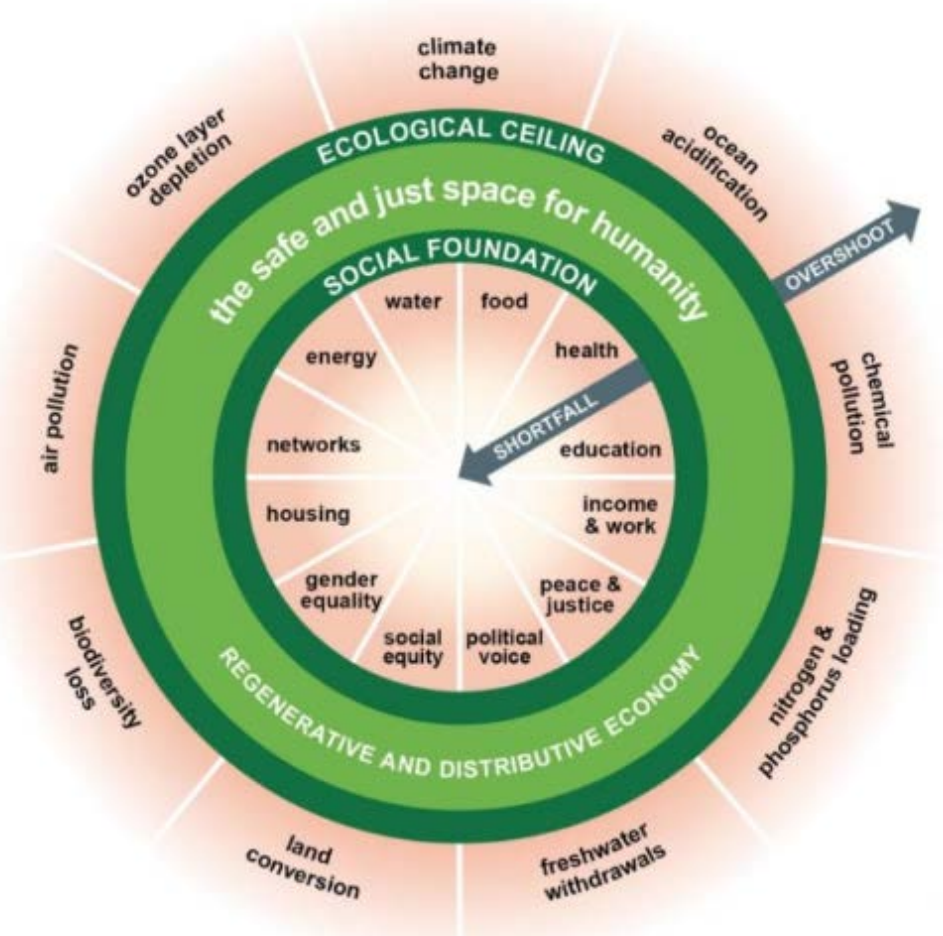

Figure 1: Planetary boundaries and social foundation. Source: Raworth $2017^{32}$

\footnotetext{
${ }^{28} \mathrm{~K}$. Raworth, 'A safe and just space for humanity: can we live within the doughnut' (2012) Oxfam Discussion Papers; Leach, Raworth and Rockström, 'Between social and planetary boundaries'.

${ }^{29}$ The additional goal is 'peace and justice'. K. Raworth, Doughnut Economics: Seven Ways to Think Like a 21stCentury Economist (Chelsea Green Publishing, 2017).

${ }^{30}$ Raworth, 'A safe and just space for humanity'; 'Human Rights and the 2030 Agenda for Sustainable Development', United Nations Human Rights Office of the High Commissioner (undated), www.ohchr.org/en/issues/SDGS/pages/the2030agenda.aspx.

${ }^{31}$ All of these rights are contained already in the milestone document of The Universal Declaration of Human Rights (UDHR), proclaimed by the United Nations General Assembly in Paris on 10 December 1948 (General Assembly resolution 217 A), Articles 3 and 25, 4, 2 and 7, and 23, respectively. For background on international human rights, see D. Shelton, The Oxford Handbook of International Human Rights Law (Oxford: Oxford University Press, 2013); for an analysis of the SDGs from a human rights perspective, see L.M. Collins, 'Sustainable Development Goals and human rights: challenges and opportunities', in D. French and L.J. Kotzé (eds.), Sustainable Development Goals. Law, Theory and Implementation (Cheltenham: Edward Elgar 2018), pp. 66-90.

32 Raworth, Doughnut Economics.
} 
This is a preprint version of Chapter1 of B. Sjåfjell and C.M. Bruner (eds), Cambridge Handbook of Corporate Law, Corporate Governance and Sustainability (Cambridge University Press, 2019)

'Planetary boundaries' and the 'social foundation' are not two separate and disconnected aspects. Rather, the relationship between them is that the social foundation is the minimum that we must seek to achieve for humanity while the planetary boundaries represent the limits for how much pressure we can put on our ecosystems to accomplish this. The interconnectedness between environmental, social, cultural, economic and governance aspects of sustainability merits emphasis:

[C]ommon social justice issues such as crumbling neighborhood infrastructure and poor access to open space and fresh food are environmental issues from the perspective of residents living in corroding and toxic neighborhoods, but these issues have traditionally been overlooked by a sustainability agenda that tends to focus on 'green' issues of ecosystem conservation rather than 'brown' issues of urban inequality. ${ }^{33}$

There are tensions inherent in global society's goal of sustainability, both as to the scientific identification of planetary boundaries and the rights-based focus on social development embodied in the SDGs, which are based on a consensus-driven inclusion of political goals with trade-offs. This points to three fundamental risks to the achievement of sustainability. First, there is a danger that ecological limits for human existence will be ignored in the battle between social goals, ironically to the immediate detriment of those whose social foundation is least firm. ${ }^{34}$ Second, there is a risk that the most marginalized groups, who arguably have not had sufficient voice in political negotiations leading up to the SDGs, will not be sufficiently recognised. ${ }^{35}$ This underlines the necessity of looking beyond the SDGs to the human rights of, notably, indigenous peoples. ${ }^{36}$ Third, and of particular relevance to the role of business and finance, there is the continual undermining of the economic bases for our societies, the increasing inequality between and within countries, and the rise of populism and the risk of societal instability that this entails. Some of the most disturbing trends in major industralised countries reflect such a lack of social stability, and corporations and associated financial markets have a role in this.

The discussion of the role of business in securing the social foundation for humanity within planetary boundaries goes to the heart of the discussion of the division of labour and responsibility between states, domestically and internationally, on the one hand, and private actors, on the other. Certainly states have an overarching responsibility in setting domestic and international frameworks to protect

\footnotetext{
${ }^{33}$ R.H.W. Boyer, N.D. Peterson, P. Arora and K. Caldwell, 'Five Approaches to Social Sustainability and an Integrated Way Forward' (2016) 8 Sustainability 878.

${ }^{34}$ For background concerning the omission of the terminology of ecological limits or planetary boundaries in the SDGs, see B. Sjåfjell, 'Redefining the Corporation for a Sustainable New Economy' (2018) 45 Journal of Law and Society 29-45.

${ }^{35}$ Achieving sustainability 'requires exploration of and debate about which combinations of pathways to pursue at different scales', and this process 'will need to be as open and inclusive as possible, giving voice to the knowledge, values and priorities of women and men who are marginalised, so that they are able to challenge powerful groups and interests'. Leach, Raworth and Rockström, 'Between social and planetary boundaries', at 88.

${ }^{36}$ That the cultural rights of indigenous peoples often are ignored is also a long-term criticism against sustainable development. See e.g. D. Weissbrodt and M. Rumsey (eds.), Vulnerable and Marginalised Groups and Human Rights (Cheltenham: Edward Elgar, 2011); Collins, 'Sustainable Development Goals and human rights' at 87-88; R. Madden and C. Coleman, 'Visibility of indigenous peoples in sustainable development indicators', working paper presented at 16th Conference of the International Association of Official Statisticians (IAOS) OECD Headquarters, Paris, France, 19-21 September 2018, www.oecd.org/iaos2018/programme/IAOSOECD2018 Madden-Coleman.pdf.
} 
This is a preprint version of Chapter1 of B. Sjåfjell and C.M. Bruner (eds), Cambridge Handbook of Corporate Law, Corporate Governance and Sustainability (Cambridge University Press, 2019)

the environment and human rights and secure the social basis for their peoples, ${ }^{37}$ notably through treaties and legislation. However, as has long been recognised, there are gaps and incoherencies in the regulatory framework - both internationally and domestically - and for the reasons discussed above in Section $2{ }^{38}$ there are inherent weaknesses in relying on a compartmentalised and fragmented regulatory framework to promote contributions to sustainability by international businesses. Corporate law and corporate governance, setting the regulatory infrastructure for corporate decision-making, therefore need to be analysed and discussed in this context, both to help support the achievement of regulatory goals in other areas of law and policy and to facilitate the internalisation of society's sustainability goals beyond what public bodies have been able to regulate.

Further, the public-versus-private discussion regarding the achievement of sustainability goals does not reflect a clear-cut dichotomy, as there is in fact no clear public/private distinction between the state and business. In some instances, states and other public bodies are directly involved in business, notably as controlling shareholders and as institutional investors. Conversely, there are prominent cases of strong corporate influence and outright corporate capture of legislation and of regulatory enforcement. A holistic perspective, encompassing public, private and hybrid forms of business and finance, must therefore inform a discussion of the contribution of business to sustainability. This implies that corporate law and corporate governance, from a sustainability perspective, must also engage with perceived political issues of inequality and living wages, with the implementation of international human rights, and with the regeneration and preservation of the ecosystems on which we depend.

All of this emphasizes that we need to recognise complexity and uncertainty as intrinsic aspects of research, policy and practice in the effort to achieve sustainability. The misleadingly simple mantra of maxisiming shareholder wealth as a proxy for business' contribution to societal welfare ${ }^{39}$ cannot be replaced by a similarly simple sustainability maximand. Instead we need to find ways to shape continuous improvement processes toward more sustainable business and finance, recognizing the work-in-progress nature of fundamental sustainability knowledge, while simultaneously maintaining that this must take place within a framework based on planetary boundaries and social, cultural, economic and environmental foundations for humanity. ${ }^{40}$

Accordingly, for purposes of this Handbook, corporate sustainability may be defined as business and finance contributing to the overarching aim of securing the social foundation for people everywhere, now and in the future, while remaining within planetary boundaries. More specifically, this involves business and finance creating value in a manner that is (a) environmentally sustainable, in that it ensures the long-term stability and resilience of the ecosystems that support human life; (b) socially sustainable, in that it facilitates the achievement of human rights and other basic social rights, as well

\footnotetext{
${ }^{37}$ For example, the right to a living wage is to be 'supplemented, if necessary, by other means of social protection', UDHR Article 23.

${ }^{38}$ The UN Guiding Principles on Business and Human Rights are an attempt to cut through that in that specific area.

${ }^{39}$ M.C. Jensen, 'Value Maximization, Stakeholder Theory, and the Corporate Objective Function' (2002)

12 no. 2 Business Ethics Quarterly 235-56.

${ }^{40}$ Leach, Raworth and Rockström, 'Between social and planetary boundaries'. On the need for 'a strengthened, interdisciplinary and politically astute science of sustainability', see ibid. at 88 .
} 
This is a preprint version of Chapter1 of B. Sjåfjell and C.M. Bruner (eds), Cambridge Handbook of Corporate Law, Corporate Governance and Sustainability (Cambridge University Press, 2019)

as good governance; and (c) economically sustainable, in that it satisfies the economic needs necessary for stable and resilient societies.

\section{Research questions and structure of the Handbook}

The foregoing dynamics require grappling with a number of pressing questions about corporate law, corporate governance, and the sustainability of resulting modes of corporate production around the world.

- How does the growing mismatch between global markets and territorially rooted national regulation affect the sustainability of corporate production and potential regulatory responses?

- How do shareholder-orientation generally, and widespread commitment to shareholder wealth maximization in particular, affect capacity to achieve corporate sustainability?

- How do trends in the organization of corporate firms, commercial markets, and financial systems affect capacity to achieve corporate sustainability?

- What innovations in corporate law and governance have these challenges prompted, and how effective can we expect them to be in achieving corporate sustainability?

- In light of the foregoing, where is further research required?

The Handbook has been designed to address these questions, marshalling analyses and insights from numerous scholars around the world. In this analysis, we concentrate on regulatory approaches to corporate law, corporate governance and sustainability, with other approaches and disciplines drawn upon to cast light on the legal analysis. We do so through the following structure:

Part I of the Handbook sets out the backdrop of global business and fragmented regulation for our analysis in the subsequent Parts.

Part II canvasses the theories that have informed the current state of business and finance, and explores the tension between legal approaches and practical realities with developments in finance challenging our understanding of business.

Part III is the heart of the Handbook. The global range of case studies through the 27 chapters of this Part provides a deeper understanding and new insights into whether, and the possible extent to which, corporate law and corporate governance are moving in a more sustainable direction.

Part IV discusses possible drivers for change, ranging from disclosure and due diligence requirements and various forms of perceived sustainability-oriented investments through other business forms, to the possibilities for legislative reform to facilitate change within the corporation itself.

In our concluding chapter we outline the insights that can be drawn from the Handbook as a whole, and reflect on the potential for the necessary changes in corporate law and governance to meet the grand challenge of our time. We also identify directions for further research and policy initiatives. 